\title{
Model Development for Decision Making in Vegetables Distribution in Kabupaten Malang
}

\author{
Teguh Oktiarso ${ }^{1}$ \\ ${ }^{1}$ Program Studi Teknik Industri, Fakultas Sains dan Teknologi, Universitas Ma Chung, Malang. \\ Email:teguh.oktiarso@machung.ac.id
}

\begin{abstract}
Food supply chain especially vegetables supply chain must consider the speed of the deliveries due to freshness of the product. Reduced of the freshness of the vegetables faces the great risk of great loss for the farmer and the greengroceries. This paper aimed to develop model for multi criteria decision making based on time to solve vegetables distribution problems from farmers to greengroceries in Kabupaten Malang. Model for decision support system is aimed to determine the minimize delivery time for main vegetables in Kabupaten Malang. There are three variables on three echelons which effects on delivery time before the vegetables decay and worthless. A model for decision support system using real data from 8 sub districts in Kabupaten Malang are obtained to describe the optimal result for several situations in vegetables distribution in Kabupaten Malang to support the decision for distributing the vegetables from farmers to greengroceries with lower cost.
\end{abstract}

Keywords: Vegetables, Supply Chain, Decision Support

\begin{abstract}
Abstrak
Rantai pasok untuk produk sayur mayur harus mempertimbangakan kecepatan pengiriman dimana hal tersebut berpengaruh pada kesegaran produk. Sayur mayur yang sudah tidak segar memperbesar resiko kerugian yang harus ditanggung oleh petani dan penjual. Penelitian ini bertujuan untuk merancang model pendukung keputusan dengan banyak kriteria dengan basis waktu untuk memecahkan permasalahan distribusi sayur mayur di Kabupaten Malang. Model untuk pendukung pengambilan keputusan dengan tiga variable untuk tiga eselon ditujukan untuk memperpendek waktu pengiriman sayur mayur sebelum menjadi layu dan akhirnya tidak dapat dijual. Model ini dibangun dengan menggunakan data riil dari 15 kecamatan di Kabupaten Malang agar dapat memberikan hasil yang optimal pada beberapa kondisi dalam distribusi sayur mayur. Dengan model yang sesuai dengan kondisi riil di Kabupaten Malang, diharapkan hasil dari sistem pendukung keputusan ini mampu memberiikan biaya distribusi yang rendah.
\end{abstract}

Kata Kunci: Sayur Mayur, Distribusi, Pendukung Keputusan

\section{Introduction}

Distribution of agricultural product is a very risky business due to short life-time of the products. Distance is the most importance variable to decide the amount of product must be pick-up and delivered. Long travel time from pick-up area to delivered area increasing the risk of decreasing of freshness of the product. Cost depends on distance and amount of the product distributed which are effected by the type of the transportation modes. (Sicilia, et al, 2013). The seller and the buyer always consider the total money spent for picking and delivered the product. When the cost is higher dan the selling price, the buyer will not buy the product from the seller and vice versa. The causes of there are no buyer came to the farmers, the agricultural product will be worthless. Farmers as seller will sell their products very cheap because they do not have any buyer.

Communication technology development such as smart phones and Google Play application has widely used by many people. Telecommunication provider has spread their $3 \mathrm{G}$ coverage area which is increasing the degree of information for all people. (Zhang, et al, 2011). The rapid telecommunication technology development could help decision makers to decide the best solutions in order to minimize cost. 
Decision support model for distribution needs many data and must be integrated between echelon or terminals (Boschian, et al, 2013). Boschian explained that an intermodal must be considered for better response in logistic. Because land transport is dominated for logistic activity, the traffic of product distribution become complex especially in loading and unloading time. (Sicilia, et al, 2013).

The aim of the research is to find better decision support model for vegetables distribution in from farmers in Kabupaten Malang to greengroceries. Decision support model is aimed to help the decision maker make good decisions for transporting vegetables from farmers which time windows is considered for the model. Problems occurs when there are no capable transportation mode to carry vegetables to the greengroceries which caused higher transportation cost. Farmers must pay full rent cost for a truck load when they only need less than truck load for sending their vegetables to only one greengrocery. This situation makes cost for transporatation became high which caused high pricing for the vegetables.

Infrastructuure for horticulture products distriburtions is not good enough for make the vegetables freshness for a long time. Infrastructures in some areas also affected to transportation mode choice. Due to the mountainous area in some area made some difficult to decide what the best mode for transporting the products.

The risk of product detriment became higher which caused lost of profit for the farmers. Greengroceries also meet vegetables shortage which caused higher price to customers. The higher price leads to higher inflation rate for East Java region.

The aim of the research is to help farmers and greengroceries to decide the best transportation mode for distributing horticulture products in Kabupaten Malang. A good distribution for horticulture products in Kabupaten Malang will raise profit for farmers and greengroceries because the products still fresh when its sells to customer. A model for supporting decision in distributing horticulture products will develop to help decision makers (farmers and greengroceries) to decide how much the farmers must harvest the plants depends on the demand, know the price, know what the transportation mode who will pick the products and know the route of the transportation mode.

When a fast decision dan the transportation has fast response to distribute the horticulture products, it will caused lower transportation cost, lower holding cost and lowering risk of products decay (Cagliano, et al, 2015). Profit for farmers and greengroceries is getting higher and the sustainability of the products is high because demand is continuous.

\section{Methods}

This research is doing with qualitative and quantitative descriptive approach in accordance with the research objectives and data required Qualitative approach is done through interviews with consumers and vegetable farmers in Malang Regency. Observations will be made to find facts in the field about the practice of supply chain or distribution of agricultural products in Malang Regency. While the quantitative approach is done to obtain and process secondary data related to information on the distribution of agricultural areas, production varieties and production capacity per year.

Raftani-Amiri, et al (2010) proposes a supply chain for agricultural products, especially food products, using a network of suppliers for food products that supply their products on a regular basis (multiperiod) with based on time windows. In the model, Raftani-Amiri describes the concept of supply chain for food products as follows: 


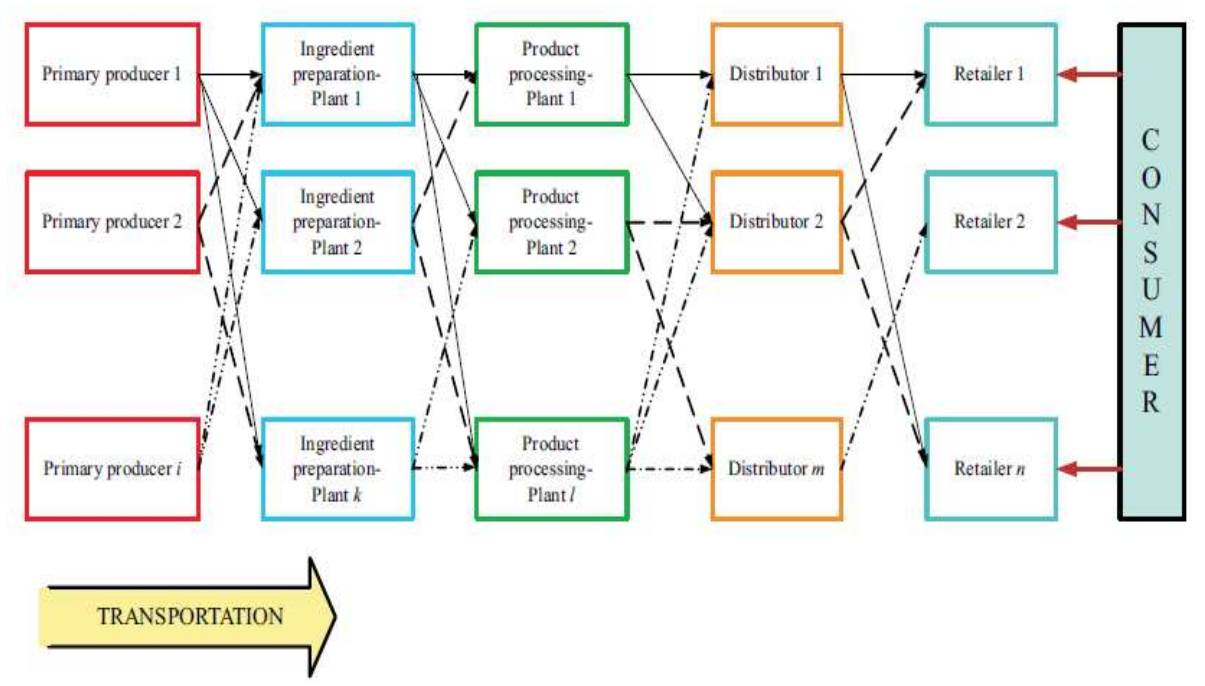

Figure 1. Supply Chain for Food Products

Source: A Multi-period Supply Network of Food Products Based on Time-Windows with Sensitivity Analysis, Z. RaftaniAmiri, et al, Operations and Supply Chain management Vol. 3, No. 2 Mei 2010, pp. 105-116

Suharyanto, et al (2008) conducted a study on the grape trading system in Bali and found that obstacles in the sale of grapes of Bali are constrained by the high price fluctuation. Price fluctuations are caused due to low productivity of grapes due to the uncertainty of natural conditions. According to Suharyanto, this will lead to a lack of ability of the wine growers in meeting market demand. Suharyanto conducted a survey to the wine farmers in Bali to determine an effective and efficient marketing channel so that uncertainty indicators can be reduced. Schemes that are generally formed in general can be explained as follows:

1. Farmer --- Wholesaler --- Collecting Dealer --- Retailer --- Consumer

2. Farmer --- Wholesaler-Retailer-Consumer

3. Farmers --- Collecting traders --- Large traders --- Retailers --- Consumers

4. Farmer --- Retailer --- Consumer

The data used in the research can be described as follows:

1. Primary data collected and processed in this study include:

i. Qualitative data in the form of verbal data resulting from interviews with farmers in Kabupaten Malang.

ii. Qualitative data in the form of photographic data used to help provide a description of the situation of facts in the field associated with varieties and availability of agricultural products in the market. This photographic data is obtained through surveys and observations.

2. Secondary data collected and processed in the research is quantitative data and obtained from Agriculture Department and Statistical Department of Kabupaten Malang about: (1) distribution of agricultural area in Malang Regency, (2) Varieties of agricultural products, (3) annual production capacity, (4) range of marketing area.

\section{Result and discussion}

In designing the model, data is the most important part in determining how models for decision support systems are designed. Data becomes input for decision support system where the output of this system is variable showing the location and amount of product to be distributed and the cost required if decision maker decides to do distribution activity. The data taken from various sources become one of the most important things in the preparation of this model so that the output generated from the system is able to answer the needs of decision makers.

The data used in the design of this model is the data associated with several variables, namely: 
a. Variable types of vegetable products produced by 8 districts in Kabupaten Malang during the last two years. Data relating to these variables will be used as determinants of what types of vegetable products are the main commodities. If known to the type of vegetables that become the main commodity, it will be easier to determine the amount of production per year and easier to determine the economic life of vegetables before not sold.

b. Variable location of vegetable farming in Malang Regency. This location will affect the distance and time of vegetable distribution. In this first model there are two gathering points namely Kepanjen and Batu, Although Kota Batu is not part of Kabupaten Malang, but to simplify the design of this early model, Kota Batu is assumed to enter into Kabupaten Malang because it will facilitate the calculation of distance. The main gathering point is the city of Malang, where from the city of Malang, vegetables are distributed to the marketing place in East Java.

c. Variable amount of crop yields of vegetable products each time the harvest. Data on these results will be used to determine the amount of capacity that can be transported by the mode of transportation. In addition to determining the capacity, the data for this variable is used to determine the mode of transportation to be used. In this initial model the transportation modes used are L300 / Gran Max as well as ankle truck / medium size truck. The choice of this mode of transportation affects the costs incurred to distribute vegetables to the destination city and determine the timing of the distribution, given that infrastructure is not necessarily good to some places.

d. Variables of vegetable demand in Kabupaten Malang. This request will certainly affect the pattern of vegetable distribution in Kabupaten Malang. The data used to support this variable is data from Disperindag of Malang Regency and data from BPS Kabupaten Malang. This demand data will be processed so that it can show the demand pattern of each type of vegetables which is the main commodity of the farmers in Kabupaten Malang. With the processed data, the determination of the location for the taking of vegetables and transportation modes to be used. All three factors will affect the amount of distribution costs.

The results of data collection for the database system for decision supporters are divided into three categories: data of vegetables that become the main commodity of the farmers, the location of vegetables which are the main commodities, and the data of production in 2016. Based on the data that has been obtained, data for variables are as follows:

a. Most commodity data is produced in Kabupaten Malang. Taken five horticultural commodities that produce the most in 2016.

Table 1. Production capacity for horticulture products

\begin{tabular}{|c|c|c|}
\hline No. & Commodity & Production (ton) \\
\hline 1 & Cabbage & 475.557 \\
\hline 2 & Shallot & 350.777 \\
\hline 3 & Tomato & 248.475 \\
\hline 4 & Chili & 243.720 \\
\hline 5 & Potato & 207.492 \\
\hline
\end{tabular}

b. Location data of five major commodities in Kabupaten Malang.

Table 2. Locations for horticulture products

\begin{tabular}{clcl}
\hline No. & \multicolumn{1}{c}{ Location } & No. & \multicolumn{1}{c}{ Location } \\
\hline 1 & Poncokusumo & 5 & Tumpang \\
2 & Ngantang & 6 & Pujon \\
3 & Wajak & 7 & Dau \\
4 & Singosari & 8 & Pakis \\
\hline
\end{tabular}


c. Location distance data to each gathering point in Kabupaten Malang that is Kota Batu and Kepanjen. The data are:

Table 3. Production capacity for horticulture products

\begin{tabular}{llc}
\hline No & \multicolumn{1}{c}{ Location } & $\begin{array}{c}\text { Distance } \\
(\mathbf{k m})\end{array}$ \\
\hline 1 & Poncokusumo & 20 \\
2 & Ngantang & 25 \\
3 & Pujon & 16 \\
4 & Singosari & 22 \\
5 & Tumpang & 25 \\
6 & Dau & 28 \\
7 & Wajak & 29 \\
8 & Pakis & 23 \\
\hline
\end{tabular}

From these data, the model for decision support for the best distribution routes and transportation modes can be draw as influence diagram below.

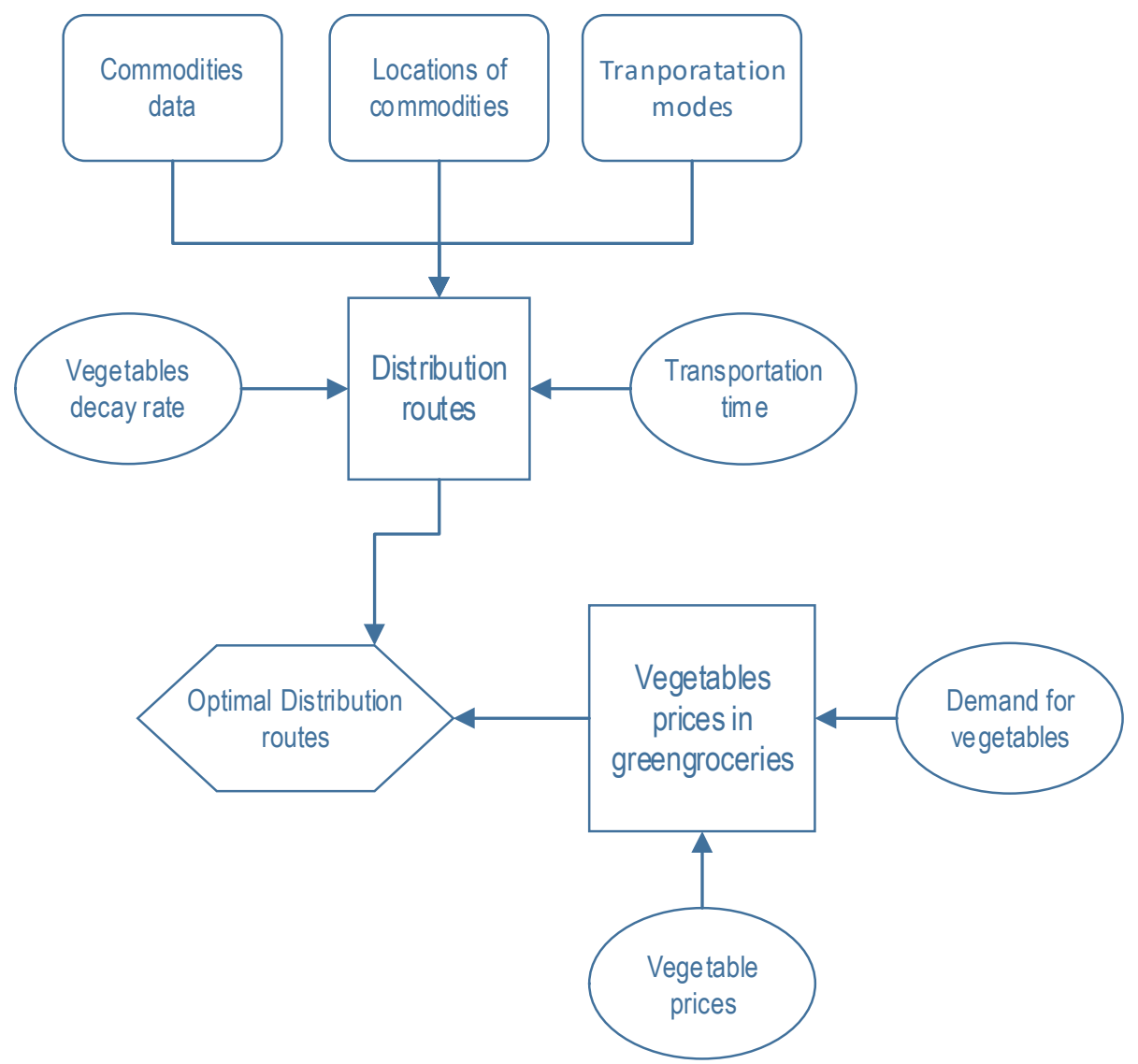

Figure 2. Influence Diagram of Distribution of Horticulture Products

Base on the influence diagram, the decision model could be built to determine the optimal distribution routes and optimal amount of every commodities in eight locations. The model could be shown as flow diagram. 


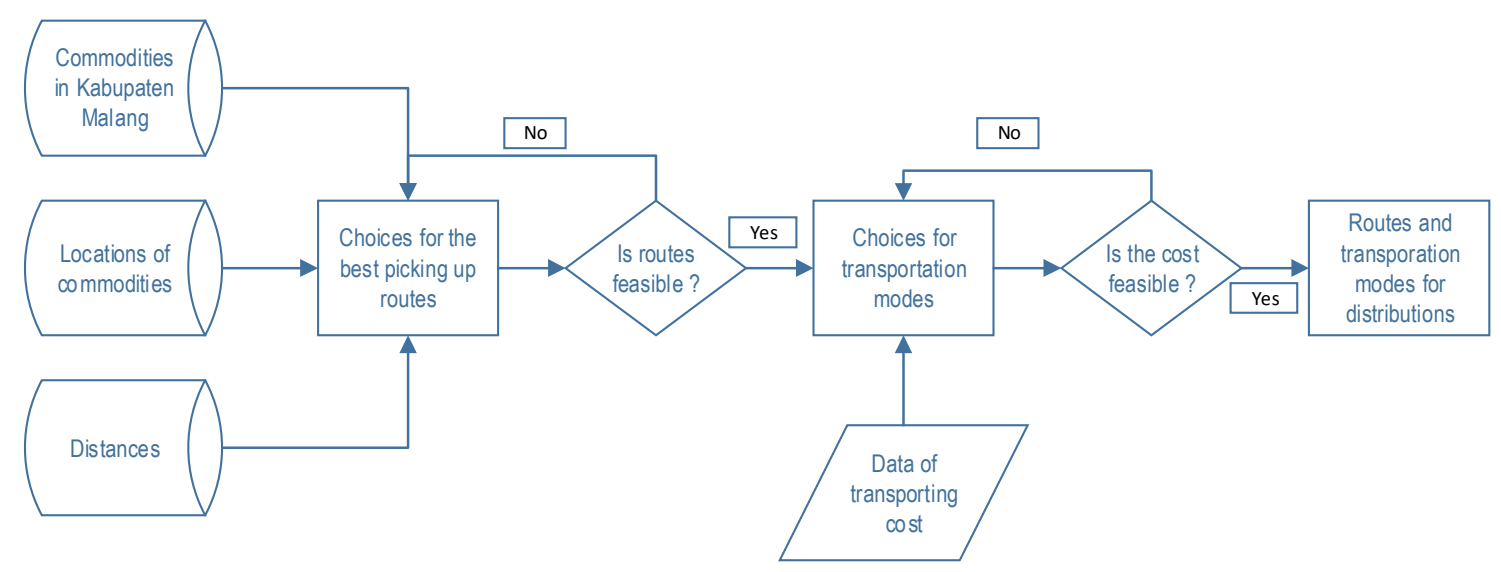

Figure 3. Model of Decision of Distribution of Horticulture Products

From the decision model, the optimal distribution routes could be defined after calculating the distances and transportation costs. Decay rate and demand of the horticulture products included in data of commodities. When the routes could not fulfill the demand of the products, the model will recalculating the routes until demand from greengroceries fulfilled. After the distribution routes found, the choices of transportation modes will be calculate to find the best modes for picking up the products from farmers. The transportation modes is set to be LTL with finite capacity. When the capacity is full, the transportation modes could not pick any products. The decision for transport mode will be infeasible if the transportation mode could not pick up products in optimal distribution routes. The model will help decision making to decide the best distribution mode which could be decreasing cost and decay rate of the horticulture product.

\section{Conclusion}

Based on the results achieved and the data collected to date, then the design of this model can be taken conclusion:

a. Data for horticulture commodities conducted on 8 sub-districts in Kabupaten Malang because 8 sub-districts is the largest producer of five top horticultural commodities Kabupaten Malang at this time

b. Data on agricultural production capacity, sub-district distance with production center and marketing area used to arrange the design of decision support model for distribution of major vegetable products in 8 sub-districts

c. Model for decision of horticulture products distributions could generate the optimal distributions route which consider all the cost and product decay.

d. Model for horticulture product distributions based on data on the five horticultural commodities which could be developed for all horticulture products in Kabupaten Malang

\section{Acknowledgments}

Author wishing to a great gratitude to Kementerian Riset dan Pendidikan Tinggi Indonesia for a chance to conduct this research by research grant which given by Direktorat Penguatan Riset dan Pengembangan.

\section{References}

Boschian, V., Fanti, M.P., Iacobellis, G., Georgoulas, G., Stylios C., and Ukovich, W. (2013) 'A Model based Decision Support System for Logistic Management' in Proccedings of European Modeling and Simulation Symposium, Jimenez

Cagliano, A.V., De Marco, A. dan Rafele C., (2015) Analysing the diffusion of a mobile service supporting the e-grocery supply chain, Business Process Management Journal, Vol. 21 No. 4: 928-963

Raftany-Amiri, Z.,Fazlollahtabar, H., dan Mahdavi-Arimi, N., (2010) A Multi-period Supply Network of Food Products Based on Time-Windows with Sensitivity Analysis, Operations and Supply Chain Management, Vol. 3, No. $2: 105-116$ 
Sicilia, J.A., Royo, B., Larrode, E. and Fraile, A. (2014) A Decision support system for long-distance routing problem based on ant colony optimization metaheuristic, Procedia - Social and Behavioral Sciences, Vol $111: 1035-1044$

Suharyanto, Parwati, I.A.P., dan Rinaldi J, (2006) Analisis Pemasaran dan Tataniaga Anggur di Bali, Jurnal SOCA, Fakultas Pertanian Universitas Udayana, Bali, Vol. 4, No. 1.

Zhang, H., Yi, S., and Wu Y., (2012) Decision Support System and Monitoring of Eco-Agriculture Based on WebGIS in Shule Basin, Energy Procedia, Vol. 14: 382-386. 